Article

\title{
Sargassum muticum Hydrothermal Extract: Effects on Serum Parameters and Antioxidant Activity in Rats
}

\author{
Elena M. Balboa ${ }^{1}$, Rosendo Millán ${ }^{2}$, Herminia Domínguez ${ }^{1}$ and Cristina Taboada ${ }^{2, *}$ \\ 1 Department of Chemical Engineering, University of Vigo (Campus Orense), As Lagoas, 32004 Ourense, \\ Spain; balboa.e.m@gmail.com (E.M.B.); herminia@uvigo.es (H.D.) \\ 2 Department of Physiology, Faculty of Pharmacy, University of Santiago de Compostela, \\ 15786 Santiago de Compostela, Spain; rosendo.millan@usc.es \\ * Correspondence: mariacristina.taboada@usc.es; Tel.: +34-881-811-000 (ext. 14924)
}

Received: 31 March 2019; Accepted: 18 June 2019; Published: 25 June 2019

check for updates

\begin{abstract}
Sargassum muticum was processed by hydrothermal extraction under previously optimized non-isothermal conditions (up to $187^{\circ} \mathrm{C}$ ). The alginate free crude hydrolysate was further concentrated by ultrafiltration, operating in diafiltration mode to produce an extract $(\mathrm{SmE})$ enriched in the fucoidan and the phlorotannin fractions and with low mineral content and antiradical capacity equivalent to that of Trolox. In order to explore the potential of this concentrated product for food or feed additive, the in vivo antioxidant potential was assessed. Male Sprague-Dawley rats were fed SmE dissolved in distilled water at doses of $0.5,1.0$ or $2.0 \mathrm{~g} \mathrm{~kg}^{-1}$, administered via an intragastric tube daily for three weeks. The weight and organ gain was not significantly affected in the different groups in relation to the control group fed a standard diet. Serum glucose was significantly lowered in the groups receiving the higher SmE doses, liver GPx levels were reduced and liver TBARS levels decreased in rats administered the extract, but no effect on SOD activity in either liver or erythrocytes was observed.
\end{abstract}

Keywords: Sargassum muticum; autohydrolysis; ultrafiltration; diafiltration; serum parameters antioxidant enzymes; lipid peroxidation

\section{Introduction}

Marine algae, containing bioactive compounds not present in terrestrial plants and beneficial to human health, are a source of phytochemical active compounds (such as polysaccharides, sterols, carotenoids and tocopherols) with antiviral, antimicrobial, antifungal, anticoagulant and antioxidant properties. Sulphated polysaccharides are widespread in marine algae, especially in brown seaweeds. The biological activities of sulphated polysaccharides include anticoagulant, antioxidant, antiviral, anticancer and immunomodulating activities [1-4]. Alginic acid has been reported to be capable of decreasing cholesterol levels, exerting an antihypertensive effect, preventing absorption of toxic products and protecting the surface membranes of the stomach and intestine [5]. Phlorotannins, polymers of phloroglucinol, which are present in brown algae, are valuable antioxidant compounds [6].

Algae are exposed to light and high concentrations of oxygen, leading them to produce oxidative agents, but algae also generate compounds that protect against oxidation [7]. Among the compounds present in algae, antioxidants have probably attracted the most interest. Brown algae possess potential antioxidant activity, and different in vitro studies have demonstrated that Sargassum spp. has compounds conferring it potent antioxidant properties [8-11]. Although scarce, the in vivo antioxidant activity of Sargassum spp. extracts have been explored. The consumption of Sargassum polycystum extracts lowers the risk of hyperglycaemia, dyslipidaemia and atherogenesis in mammalian models of type 2 diabetes [12,13]. 
Sargassum muticum, an invasive brown algae on the Atlantic coasts, represents an important environmental problem and can also affect recreational activities in coastal areas. Eradication trials were unsuccessful, and periodic removal of specimens has proven effective in preventing further spread. Therefore, valorization of the removed biomass has been proposed. Hydrothermal processing offered higher biomass solubilization yields than other intensification methods [14] and conforms a suitable strategy for the extraction and depolymerization of the fucoidan fraction $[15,16]$. Further processing with ultrafiltration membranes allowed the concentration in bioactives and the elimination of minerals in the concentrated product [17]. Some fractions could be especially enriched in bioactives [18].

Reactive oxygen species (ROS) cause damage to biomolecules and participate in the development of many disorders and diseases. ROS may be highly damaging, as they can attack biological macromolecules (namely lipids, proteins and DNA), induce oxidation and cause membrane damage, enzyme inactivation and DNA damage [19]. Oxidative stress is considered to play a pivotal role in the pathogenesis of aging and several degenerative diseases such as atherosclerosis, cardiovascular disease, type 2 diabetes and cancer [20]. ROS scavenging or detoxifying mechanisms involve enzymatic and non-enzymatic antioxidants, either those produced in the body (i.e., endogenous antioxidants) [21] or those supplied in the diet [22]. Antioxidant enzymes such as superoxide dismutase (SOD), catalase (CAT) and glutathione peroxidase (GPx) act by catalyzing the decomposition of oxidants and free radicals and exerting protective effects against cellular damage [23]. Methods of increasing antioxidant capacity have been suggested as being potentially useful for preventing or delaying the adverse actions of ROS.

In this study, the in vivo antioxidant properties of Sargassum muticum hydrothermal extracts were evaluated by examining the effects on the antioxidant enzyme activity in growing male Sprague-Dawley rats fed with a diet supplemented with these extracts. The activity of the antioxidant enzymes superoxide dismutase (SOD), catalase (CAT) and glutathione peroxidase (GPx) in liver and in red blood cells were determined and the total amounts of lipid peroxidation products in liver were assayed. The effects of the algal extract on serum parameters and body weight of rats was also determined.

\section{Results and Discussion}

\subsection{Extract Composition and Characteristics}

The concentrated Sargassum muticum extract evaluated in this study was produced according to the scheme shown in Figure 1. The hydrothermal extract produced by hydrothermal processing in hot pressurized water media was further concentrated in membranes during successive washing cycles to selectively remove low molecular weight components. The salt content in the concentrated product (SmE) obtained after the ultrafiltration stage operating in the diafiltration mode was reduced by almost six times, to less than $2 \%$ of the dry weight. The arsenic content in the product was lowered to a safe-to-use concentration $\left(0.4 \mu \mathrm{g} \mathrm{g}^{-1}\right)$ from the original value of the autohydrolysis crude extract, which was $29.4 \mu \mathrm{g} \mathrm{g}^{-1}$. The fucoidan content accounted for more than $50 \%$ of the product dry weight, being fucose the most abundant constituent, followed by galactose, glucose, xylose and mannose; with an average sulfation of $7 \%$. Along the diafiltration process the phenolic content of the concentrated product could be increased up to $10-15 \%$. The SmE product showed antiradical properties equivalent to $20 \%$ of those presented by Trolox [17]. The fractions with molecular weight in the range of 50-100 kDa and that with more than $100 \mathrm{kDa}$ contained higher phenolic and sulfate content. Both could be responsible for the biological properties, in particular for cytotoxicity against tumoral cells and antioxidant capacity. However, those fractions under $5 \mathrm{kDa}$ contribute in lower extent to these properties. 


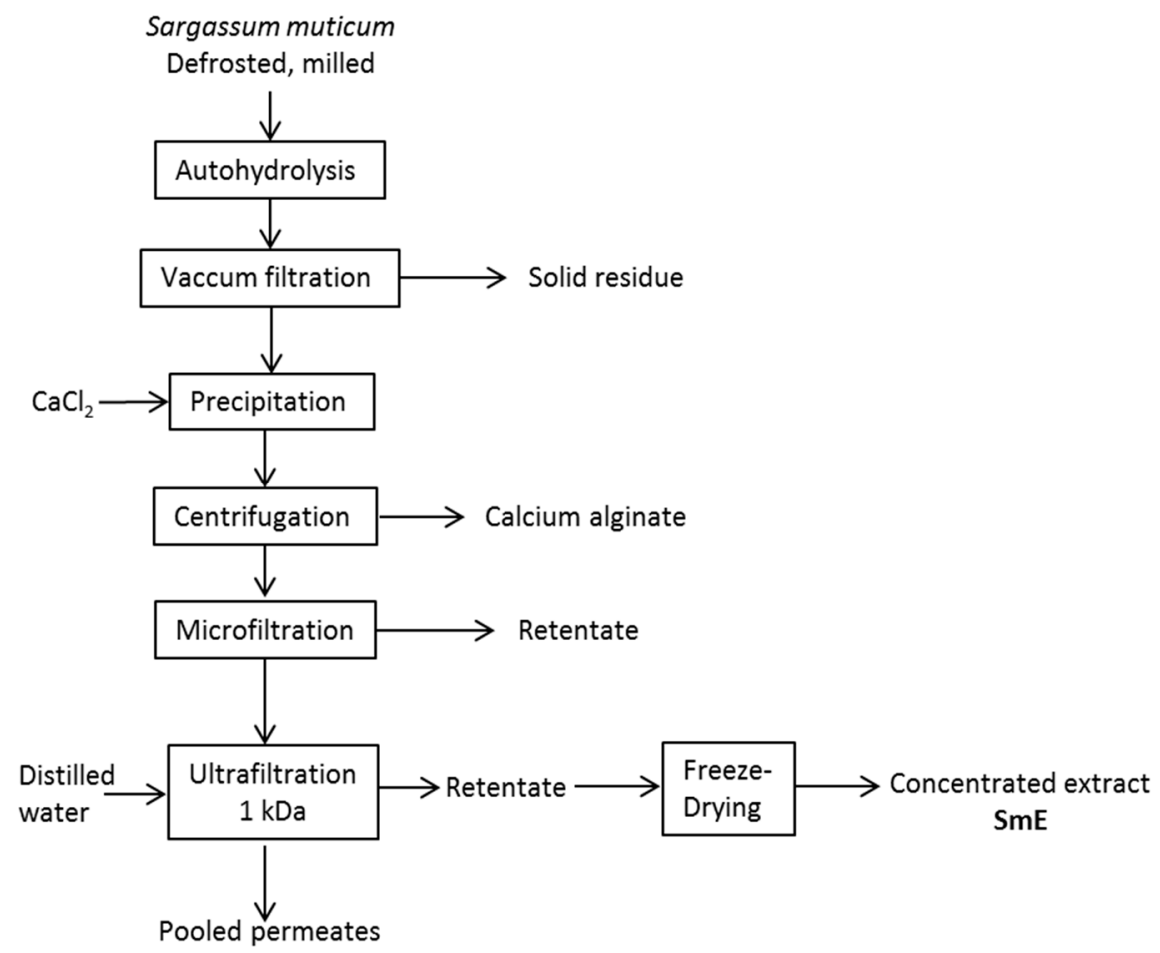

Figure 1. Flowchart of the extraction and concentration of the Sargassum muticum concentrated extract $(\mathrm{SmE})$.

The Fourier transform infrared spectroscopy (FT-IR) spectra of the concentrated product (Figure 2a) shows characteristic absorption bands in the following regions: $2923 \mathrm{~cm}^{-1}$, corresponding to C-H stretching; at $1629 \mathrm{~cm}^{-1}$, corresponding to carbohydrate $\mathrm{O}-\mathrm{C}-\mathrm{O}$ asymmetric stretching vibrations; $1421 \mathrm{~cm}^{-1}$, corresponding to $\mathrm{C}-\mathrm{OH}$ deformation vibration; and $1384 \mathrm{~cm}^{-1}$, corresponding to $\mathrm{C}-\mathrm{C}-\mathrm{H}$ and $\mathrm{O}-\mathrm{C}-\mathrm{H}$ deformation. Shoulders at $1260 \mathrm{~cm}^{-1}$ correspond to $\mathrm{S}=\mathrm{O}$ stretching vibration of the sulfate. The bands in the $1064 \mathrm{~cm}^{-1}$ region correspond to $\mathrm{C}-\mathrm{O}$ and $\mathrm{C}-\mathrm{C}$ stretching vibrations, and those in the $820 \mathrm{~cm}^{-1}$ region correspond to the $\mathrm{C}-\mathrm{O}-\mathrm{S}$ vibration of sulfate groups.

The GPC chromatogram (Figure $2 b$ ) shows that the concentrated product is distributed in fractions higher than $50 \mathrm{kDa}$ and a smaller fraction between 5 and $12 \mathrm{kDa}$, whereas the original hydrolysate included a wider distribution of different molecular weight fractions, also corresponding to low polymerization degrees [16].

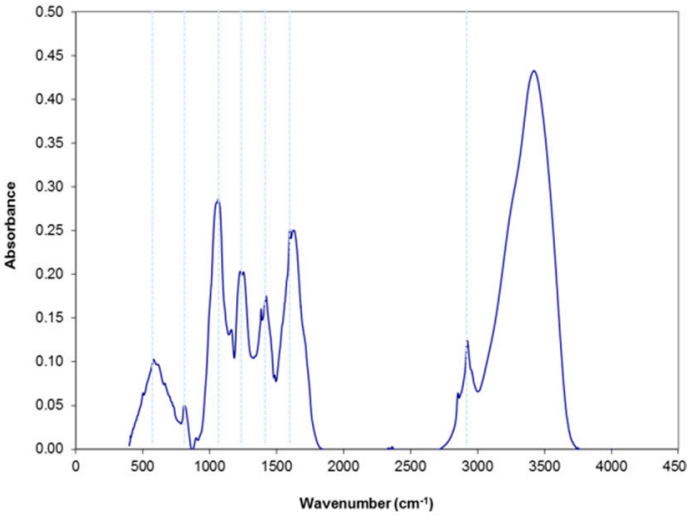

(a)

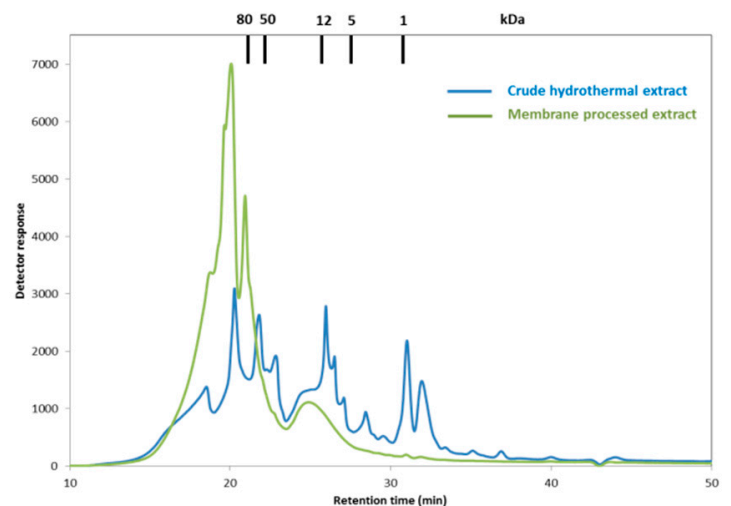

(b)

Figure 2. (a) The Fourier transform infrared spectroscopy (FT-IR) spectra of the concentrated product and (b) gel permeation chromatography (GPC) chromatogram of hydrolysate after autohydrolysis (blue line) and concentrated product (green line). 


\subsection{Effect of Administration}

\subsubsection{Influence on Weight}

Administration of S. muticum extracts did not affect the rate of increase in body weight of rats during the growth period (Table 1) and there were very few modifications considering the individual relative weight of organs in response to the administration of all three doses. However, in a similar study, Zaragozá et al. [24] observed an increase in the relative weight of the kidneys of rats administered in a dose of $750 \mathrm{mg} \mathrm{kg}^{-1}$ of Fucus vesiculosus extracts, whereas administration of $200 \mathrm{mg} \mathrm{kg}^{-1}$ did not modify this parameter. In another study, the administration of an Ulva rigida extract to Wistar rats during a period of five weeks did not alter the body weight nor the triglycerides when compared to the control group, although the total cholesterol levels were lower [25]. In the present study, no significant differences in either the total cholesterol levels or in the different fractions between the control and treated groups were observed. However, although both the level of glycaemia and triglycerides in plasma decreased in the rats fed with the Sargassum extract, the reduction was not significant. Tas et al. [25] suggested that flavonoids and other phytochemicals may lower plasma levels of glucose as the serum concentration of insulin increases. Daech et al. [26] reported that the ability of polysaccharides to reduce glycaemia levels may be due to modulation of the immune system and because they can improve the production of short-chain fatty acids by the intestinal microbiota thereby inhibiting the absorption of intestinal glucose.

Table 1. Trophic balance in rats control and Sargassum muticum extract treated groups. Values are mean \pm SEM. Number of animals per group $=6$.

\begin{tabular}{|c|c|c|c|c|}
\hline Trophic Balance & Control & $0.5 \mathrm{~g} \mathrm{~kg}^{-1}$ & $1.0 \mathrm{~g} \mathrm{~kg}^{-1}$ & $2.0 \mathrm{~g} \mathrm{~kg}^{-1}$ \\
\hline Weight gain $\left(\mathrm{g} \mathrm{day}^{-1}\right)$ & $6.79 \pm 0.15$ & $7.02 \pm 0.11$ & $6.93 \pm 0.11$ & $6.79 \pm 0.22$ \\
\hline Liver/body weight (\%) & $3.30 \pm 0.04$ & $3.43 \pm 0.07$ & $3.35 \pm 0.08$ & $3.42 \pm 0.04$ \\
\hline Kidney/body weight (\%) & $0.86 \pm 0.00$ & $0.79 \pm 0.02 *$ & $0.79 \pm 0.02 *$ & $0.81 \pm 0.01 *$ \\
\hline Intestinal mucosa/body weight (\%) & $0.85 \pm 0.01$ & $0.87 \pm 0.03$ & $0.74 \pm 0.02$ & $0.80 \pm 0.05$ \\
\hline Heart/body weight $(\%)$ & $0.41 \pm 0.00$ & $0.41 \pm 0.00$ & $0.42 \pm 0.01$ & $0.39 \pm 0.01$ \\
\hline Lung/body weight (\%) & $0.55 \pm 0.01$ & $0.48 \pm 0,03$ & $0.59 \pm 0.02 *$ & $0.53 \pm 0.07$ \\
\hline Stomach/body weight (\%) & $0.62 \pm 0.03$ & $0.59 \pm 0.02$ & $0.57 \pm 0.02$ & $0.64 \pm 0.02$ \\
\hline
\end{tabular}

* Significant difference from the control group at $p<0.05$.

\subsubsection{Influence on Serum Parameters}

Seaweed supplementation can lower blood levels of triglycerides in diabetes patients [27]. This effect may occur via the inhibition of fatty acid synthesis by fermentation products or by changes in intestinal motility [28]. Increased levels of high-density lipoprotein and decreased levels of triglycerides are positive effects that may reduce the incidence of cardiovascular diseases.

In this respect, the reduction in lipid peroxidation induced by the ingestion of the Sargassum extract may reduce the deleterious effects due to free radicals. No significant differences in the levels of the other serum parameters analyzed were observed in relation to administration of S. muticum extract (Table 2). 
Table 2. Serum parameters in control rats and Sargassum muticum extract treated groups. Values are mean \pm SEM. Number of animals per group $=6$.

\begin{tabular}{|c|c|c|c|c|}
\hline Serum Parameters & Control & $0.5 \mathrm{~g} \mathrm{~kg}^{-1}$ & $1 \mathrm{~g} \mathrm{~kg}^{-1}$ & $2 \mathrm{~g} \mathrm{~kg}^{-1}$ \\
\hline $\mathrm{CHO}$ total $\left(\mathrm{mg} \mathrm{dL}^{-1}\right)$ & $121.50 \pm 3.96$ & $118.17 \pm 3.24$ & $118.50 \pm 5.36$ & $114.83 \pm 2.96$ \\
\hline $\mathrm{HDL}\left(\mathrm{mg} \mathrm{dL}^{-1}\right)$ & $49.50 \pm 1.30$ & $48.80 \pm 1.53$ & $48.10 \pm 2.09$ & $45.33 \pm 1.15$ \\
\hline $\operatorname{LDL}\left(\mathrm{mg} \mathrm{dL}^{-1}\right)$ & $51.70 \pm 2.94$ & $50.70 \pm 1.71$ & $45.08 \pm 2.27$ & $46.43 \pm 2.14$ \\
\hline Triglycerides $\left(\mathrm{mg} \mathrm{dL}^{-1}\right)$ & $105.75 \pm 6.21$ & $98.23 \pm 6.23$ & $86.50 \pm 5.70$ & $97.17 \pm 8.19$ \\
\hline $\mathrm{BUN}\left(\mathrm{mg} \mathrm{dL}^{-1}\right)$ & $11.25 \pm 0.34$ & $11.33 \pm 0.76$ & $13.00 \pm 0.71$ & $12.00 \pm 0.95$ \\
\hline Total protein $\left(\mathrm{g} \mathrm{dL}^{-1}\right)$ & $5.40 \pm 0.05$ & $5.57 \pm 0.08$ & $5.50 \pm 0.11$ & $5.37 \pm 0.09$ \\
\hline Albumin $\left(\mathrm{g} \mathrm{dL}^{-1}\right)$ & $4.15 \pm 0.058$ & $4.30 \pm 0.05$ & $4.13 \pm 0.12$ & $4.13 \pm 0.03$ \\
\hline GOT (UI L $\left.{ }^{-1}\right)$ & $127.50 \pm 8.14$ & $157.83 \pm 11.46$ & $167.50 \pm 24.46$ & $164.67 \pm 19.81$ \\
\hline GPT (UI L $\left.{ }^{-1}\right)$ & $23.25 \pm 2.28$ & $21.83 \pm 4.00$ & $26.00 \pm 1.71$ & $29.00 \pm 3.97$ \\
\hline Glucose $\left(\mathrm{mg} \mathrm{dL}^{-1}\right)$ & $100.80 \pm 3.28$ & $95.83 \pm 3.06$ & $90.78 \pm 2.76$ & $82.40 \pm 2.55$ \\
\hline
\end{tabular}

Serum parameter abbreviations: $\mathrm{CHO}$, total cholesterol; HDL, high density lipoprotein cholesterol; LDL, low density lipoprotein cholesterol; BUN, blood urea nitrogen; GOT, glutamic oxaloacetic transaminase; GPT, glutamic pyruvic transaminase.

\subsubsection{Influence on Antioxidant Biomarkers}

\section{Enzymes}

Antioxidants can act by ROS scavenging or inhibiting lipid peroxidation. Endogenous antioxidant enzymes such as SOD, GPx and CAT provide protection against ROS. Among marine algae, the Sargassaceae family has been found to exhibit the highest radical scavenging activity [29].

In the present study, we determined the activities of the antioxidant enzymes SOD, GPx and CAT in liver and red blood cells of the rats in relation to administration of the S. muticum extract. The total amount of lipid peroxidation products was assayed by quantifying thiobarbituric acid reactive substances (TBARS), which are often used as oxidation markers.

Data in Table 3 summarize the influence of the extract on the lipid peroxidation and antioxidant enzymes. Results indicate a significant reduction of $62.68 \%$ in liver GPx (U.mg ${ }^{-1}$ prot.) and of $45.27 \%$ in TBARS levels for the SmE fed rats at 0.5 and $1 \mathrm{~g} \mathrm{Kg}^{-1}$, respectively, but no effect was shown on SOD activity in either liver or erythrocytes. In a similar study, erythrocytic TBARS levels of diabetic patients supplemented with seaweeds were lower than in controls; catalase and GSH-Px activities were higher in the treated group than in controls, but SOD was not affected by the seaweed supplement [27].

Table 3. Activity of lipid peroxidation and antioxidants enzymes in control rats and Sargassum muticum extract-treated groups. Values are mean \pm SEM. Number of animals per group $=6$.

\begin{tabular}{lcccc}
\hline \multicolumn{1}{c}{ Enzyme } & Control & $\mathbf{0 . 5} \mathbf{g ~ k g}^{\mathbf{- 1}}$ & $\mathbf{1 . 0} \mathbf{g ~ k g}^{-\mathbf{1}}$ & $\mathbf{2 . 0} \mathbf{g ~ k g}^{-\mathbf{1}}$ \\
\hline SOD hemolyzed $\left(\mathrm{U} \cdot \mathrm{mg}^{-1} \mathrm{Hb}\right)$ & $11.33 \pm 2.02$ & $9.00 \pm 1.81$ & $14.46 \pm 2.78$ & $13.27 \pm 3.57$ \\
SOD liver $\left(\mathrm{U} \cdot \mathrm{mg}^{-1} \mathrm{prot}^{-}\right)$ & $35.09 \pm 1.80$ & $34.55 \pm 1.24$ & $32.71 \pm 1.18$ & $35.51 \pm 0.96$ \\
GPx hemolyzed $\left(\mathrm{U} \cdot \mathrm{mg}^{-1} \mathrm{Hb}\right)$ & $1422.02 \pm 162.87$ & $1036.83 \pm 183.74$ & $1568.59 \pm 212.84$ & $1368.04 \pm 283.80$ \\
GPx liver $\left(\mathrm{U} \cdot \mathrm{mg}^{-1} \mathrm{prot}\right)$ & $1306.18 \pm 39.35$ & $536.75 \pm 69.13^{*}$ & $487.49 \pm 35.90^{*}$ & $528.55 \pm 44.6^{*}$ \\
CAT hemolyzed $\left(\mu \mathrm{mol} \mathrm{H} \mathrm{O}_{2} \cdot \mathrm{mg}^{-1} \mathrm{Hb}\right)$ & $752.60 \pm 95.72$ & $630.82 \pm 143.89$ & $884.28 \pm 167.33$ & $726.53 \pm 182.14$ \\
CAT liver $\left(\mu \mathrm{mol} \mathrm{H}_{2} \mathrm{O}_{2} \cdot \mathrm{mg}^{-1} \mathrm{Hb}\right)$ & $1551.92 \pm 38.42$ & $1450.28 \pm 37.02$ & $1460.20 \pm 61.52$ & $1458.94 \pm 35.48$ \\
TBARS liver $\left(\mathrm{nmol} \mathrm{MDA} \cdot \mathrm{mg}^{-1}\right.$ prot$)$ & $2.43 \pm 0.21$ & $1.33 \pm 0.09 *$ & $1.53 \pm 0.08^{*}$ & $1.82 \pm 0.12$ \\
\hline
\end{tabular}

* Significant difference from the control group at $p<0.05$.

Catalase affects cellular resistance to toxicity induced by hydrogen peroxide and it is responsible for eliminating $\mathrm{H}_{2} \mathrm{O}_{2}$. The ROS scavenging activity of SOD is therefore consistent with the action of CAT because SOD generates $\mathrm{H}_{2} \mathrm{O}_{2}$, which must be scavenged by CAT [24,30]. However, significant variations in catalase activity were not observed in either liver or erythrocytes of rats administered the Sargassum extracts. The antioxidant effects of diverse substances may be particularly low under conditions of stress, but possibly do not have any effect under conditions of no stress. 


\section{Other Antioxidant Compounds}

Potential antioxidant compounds are widely distributed in seaweeds and act by scavenging ROS and inhibiting peroxidation.

Guerra Dore et al. [31] tested various doses of isolated fucan from Sargassum vulgare and observed anticoagulant, antithrombotic and anti-inflammatory activity, but low antioxidant activity. In a similar way, Kellogt and Lila [32] tested the ability of fractionated extracts of marine algae to scavenge the DPPH radical. The red alga Pyropia fallax and the green alga Ulva lactuca did not show any detectable antioxidant activity. However, some species of brown algae have been found to display a high capacity to scavenge ROS and lower NO production. Marudhupandi et al. [33] found that the antioxidant activity of fucoidan depended on the sulphate content of the extract. There appears to be some variability in the antioxidant capacity of algal extracts and their sulphate content [34].

Some products with low phenolic content have shown antioxidative effects. It is therefore possible that other compounds may also contribute to the antioxidant properties of seaweeds [35]. Muroney et al. [36] did not observe any differences in the levels of oxidation of extrahepatic tissue in pigs fed diets supplemented with extracts of Laminaria spp. This led these authors to consider that three weeks of dietary supplementation was not sufficient to induce significant changes. The findings of a recent study by Zhao et al. [6] indicated that phlorotannin extracted from Sargassum hemiphyllum exerts antioxidant activity against induced oxidative damage in the liver, kidney and brain.

In the present study, the fact that the administration of the Sargassum extract significantly decreased lipid peroxidation may have led to a parallel reduction in the mechanisms of defense against oxidation. Further studies are required in order to determine if polysaccharides and/or phlorotannins from algal extracts display antioxidant activity, how the action is exerted and whether the effect is only manifested under conditions of induced stress.

\section{Materials and Methods}

\subsection{Materials}

Specimens of Sargassum muticum were collected by hand from Mourisca beach (Alcabre, North-West of Spain) in June 2012 and stored at $-18^{\circ} \mathrm{C}$ until use. Sampling was carried out in June because the concentrations of phenolics and fucoidan in this species are maximal in Summer [11,16,37]. Before use, the algal material was defrosted, cleaned, rinsed with tap water, and minced.

\subsection{Extraction and Concentration}

Briefly, the autohydrolysis process was carried out as follows: Four hundred $\mathrm{g}$ of dried equivalent algal material was mixed with water, at a liquid: Solid ratio of 30:1 (w/w, dry basis), and was heated in a 12 L stainless steel reactor PARR 4843 (Parr Instr. Co., Moline, IL, USA) until reaching a temperature of $187^{\circ} \mathrm{C}$ (Simpson severity factor of autohydrolysis process $=3.46$ ). Once the target temperature was reached, the reactor was immediately cooled, and the liquid and solid phases were separated by vacuum filtration with a Büchner funnel. The process was repeated until $50 \mathrm{~L}$ of liquid extract was obtained.

Consecutively, the liquid extract obtained in the autohydrolysis process was subjected to membrane concentration. Firstly, it was passed through a spiral polymeric microfiltration membrane (diameter $60.7 \mathrm{~mm}$, length $101.6 \mathrm{~cm}$; lberlact, Spain) to remove macroparticles. The remaining alginate of the permeate was precipitated by adding $1 \%$ of dry equivalent $\mathrm{CaCl}_{2}$ dihydrate $(99 \%$, ACS reagent, Acros Organics $^{\mathrm{TM}}$, Belgium) and stirring overnight. Then, the supernatant $(4 \mathrm{~L})$ was concentrated to half volume by passing it through a $1 \mathrm{KDa}$ vertical spiral regenerated cellulose membrane (diameter $56 \mathrm{~mm}$, length $39.9 \mathrm{~cm}$, Prep/Scale TFF 6 Cartridge; EMD Millipore, Burlington, MA, USA). The permeate was stored and the process was repeated in order to concentrate all the liquid extract obtained by autohydrolysis. Permeates from repeated batches were pooled, as were the concentrates. Finally, the pooled concentrate was mixed with water (1:1) and further subjected to repeated diafiltration 
through the same (cleaned) $1 \mathrm{KDa}$ membrane to remove salts. Diafiltration was monitored by determining the salt content of the retentate, monitored by comparing the $\mathrm{pH}$ of the liquid extract against a $\mathrm{pH}-\mathrm{CaCl}_{2}$ concentration standard curve. The process was stopped after seven diafiltration cycles, when the concentration of the retentate reached values lower than $2 \mathrm{~g} \mathrm{CaCl}_{2}$ equivalent $\mathrm{L}^{-1}$. The final retentate (R7) was freeze-dried and stored until analysis. A flow chart of the process is shown in Figure 1.

\subsection{Experimental Animals and Diets}

The study followed the general guidelines for the care and use of laboratory animals, as recommended by the Council of European Communities (Council of European Communities, 1986). All experiments were approved by the Ethics Committee of the University of Santiago de Compostela (15007AE/09/FUN 01/FIS [02]). Male Sprague-Dawley rats of initial body weight 90-100 g, obtained from the Animal Service Centre of the University of Santiago de Compostela, were housed in an air-conditioned room, which was maintained at a temperature of approximately $22^{\circ} \mathrm{C}$, with a $12 \mathrm{~h}$ light $/ 12 \mathrm{~h}$ dark cycle and free access to food and water. The rats were fed a standard powdered A04 diet (Scientific Animal Food \& Engineering, Augy, France) and were divided into four groups. After an acclimation period of five days before the start of the experiment, the control group was administered distilled water via an intragastric tube. The other three groups were administered the S. muticum extract, dissolved in distilled water to produce doses of $0.5,1.0$ or $2.0 \mathrm{~g} \mathrm{~kg}^{-1}$, also via an intragastric tube. The extracts (or distilled water) were administered daily for three weeks.

At the end of the experimental period, the rats were fasted overnight and killed by decapitation with a guillotine. The liver, kidney, stomach, lungs and heart were removed immediately, rinsed with cold $0.9 \%(\mathrm{w} / \mathrm{v}) \mathrm{NaCl}$ buffer, dried and weighed. The intestines were also extracted and scraped to obtain the intestinal mucosa.

\subsection{Serum Biochemical Parameters}

At the end of the experimental period, a sample of blood was obtained from each rat and centrifuged at $1300 \mathrm{~g}$ for $10 \mathrm{~min}$. The serum obtained was used for biochemical determinations with a Spotchem SP-4410 autoanalyser.

\subsection{Preparation of Tissues for Measurement of Antioxidant Levels}

\subsubsection{Preparation of Liver Samples}

Samples of liver were homogenized (1:4 w/v) in ice-cold $0.25 \mathrm{M}$ sucrose solution, in an Ultraturrax T-25 homogenizer (Ika, Germany). The homogenate was centrifuged at $100,000 \times g$ for 60 min at $4{ }^{\circ} \mathrm{C}$ in a Beckman ultracentrifuge. The supernatant fraction was decanted and used to determine SOD and GPx activities. For the catalase assay, the homogenate containing $1 \mathrm{~mL}$ of $0.9 \%(\mathrm{w} / \mathrm{v}) \mathrm{NaCl}$ was centrifuged at $1000 \times g$ for $10 \mathrm{~min}$ at $4{ }^{\circ} \mathrm{C}$. Protein concentrations in the supernatants were measured using bovine serum albumin as the reference standard [38].

\subsubsection{Blood Sample Preparation}

Immediately after the rats were decapitated, blood samples were collected in heparinized tubes. The heparinized blood was centrifuged for $10 \mathrm{~min}$ at $3000 \times g$ and $4{ }^{\circ} \mathrm{C}$ to obtain erythrocytes. The buffy coat on the erythrocyte sediment was separated carefully after the plasma was removed. The erythrocyte sediment was washed three times with two volumes of a cooled isotonic $\mathrm{NaCl}$ solution to remove the plasma remnant. After each procedure, the erythrocyte-saline mixture was centrifuged at $3000 \times g$ for $10 \mathrm{~min}$ at $4{ }^{\circ} \mathrm{C}$. The erythrocytes were then lysed with cold distilled water (1:1), vortexed for $1 \mathrm{~min}$, and stored in a refrigerator at $4{ }^{\circ} \mathrm{C}$ for $15 \mathrm{~min}$. The cell debris was removed by centrifugation at $4500 \times g$ for $15 \mathrm{~min}$. The haemolysate was stored at $-80^{\circ} \mathrm{C}$ until being assayed. The haemoglobin concentration in the haemolysate was determined by the cyanmethemoglobin method [39]. 


\subsection{Measurement of Lipid Peroxidation Levels}

Lipid peroxidation was assayed by the thiobarbituric acid reactive substances (TBARS) procedure [40]. Samples $(0.5 \mathrm{~mL})$ previously treated with $25 \mu \mathrm{L}$ of butylated hydroxytoluene $(1 \% \mathrm{w} / \mathrm{v}$ in glacial acetic acid) were mixed with $0.2 \mathrm{~mL}$ of sodium laurylsulphate $(8 \% \mathrm{w} / \mathrm{v}), 1 \mathrm{~mL}$ of acetic acid $(20 \% \mathrm{w} / \mathrm{v})$ and $1 \mathrm{~mL}$ of $0.8 \%(\mathrm{w} / \mathrm{v}) 2$-thiobarbituric acid, and the mixture was heated at $95^{\circ} \mathrm{C}$ for $30 \mathrm{~min}$. The resulting chromogen was extracted with $3 \mathrm{~mL}$ of $n$-butyl alcohol and centrifuged at $1000 \times g$ for $10 \mathrm{~min}$. The absorbance of the organic phase was measured at $532 \mathrm{~nm}$ in a spectrophotometer, with 1 , 1, 3, 3-tetraethoxypropane as the reference standard.

\subsection{SOD Measurement}

SOD (EC 1.15.1.1) activity was determined by a modified version of the method described by Beauchamp and Fridovich [41]. The activity was measured with the RANSOD test kit (Randox Laboratories Ltd., Crumlin, UK), which is based on the ability of the test substance to prevent formation of formazan from 2-(4-iodophenyl)-3-(4-nitrophenol)-5-phenyltetrazolium chloride (INT) by superoxide radicals generated by xanthine oxidase/xanthine. Formazan formation was recorded spectrophotometrically at $505 \mathrm{~nm}$. Inhibition of $50 \%$ of the INT oxidation after reduction of the sample was defined as one unit of SOD activity.

\subsection{Measurement of GPx Activity}

GPx (EC 1.11.1.9) activity was assayed with Ransel test kits (Randox Laboratories Ltd., UK) [42]. Conversion of NADPH to $\mathrm{NADP}^{+}$was monitored continuously in a spectrophotometer at $340 \mathrm{~nm}$ for $3 \mathrm{~min}$. GPx activity was expressed as moles of NADPH oxidized to $\mathrm{NADP}^{+}$per minute per milligram of protein of the sample.

\subsection{Measurement of Catalase Activity}

Catalase (EC 1.11.1.6) activity was determined spectrophotometrically by a modified version of the method described by Aebi [43], based on the measurement of the hydrogen peroxide substrate remaining after the catalase reaction. Catalase first converts hydrogen peroxide to water and oxygen, and the enzymatic reaction is stopped with sodium azide. An aliquot of the reaction mixture is then assayed for the remaining amount of hydrogen peroxide, by a colorimetric method that uses a substituted phenol (3,5-dichloro-2-hydroxybenzenesulfonic acid), which oxidatively couples to 4 -aminoantipyrine in the presence of hydrogen peroxide and horseradish peroxidase (HRP). The amount of red quinoneimine dye ( $\mathrm{N}$-(4-antipyryl)-3-chloro-5-sulfonate-p-benzoquinone- monoimine) produced was quantified at $520 \mathrm{~nm}$. The concentration of hydrogen peroxide used in this assay $(50 \mathrm{~mm})$ provides a measurable signal, but does not cause inactivation of the enzyme. The catalase activity was expressed as micromoles of $\mathrm{H}_{2} \mathrm{O}_{2}$ decomposed per minute per milligram of protein.

\section{Conclusions}

Sargassum muticum algal material is a potential feedstock that can be processed by autohydrolysis and ultrafiltration with membranes to obtain fucoidan and phlorotannin-rich extracts, with low mineral content, antiradical capacity equivalent to that of Trolox, and in vivo antioxidant potential in animal studies (decreased serum glucose, reduced liver GPx and TBARS levels with no body and organ weight gain).

\section{Statistical Analysis}

Data were expressed as mean values and the corresponding standard errors (SEM). Statistical analysis was carried out with SPSS, version 17.0, for Windows (Chicago, IL, USA). The results were analyzed by one-way analysis of variance (ANOVA) followed by a post hoc Tukey's test (when significant differences were detected). Differences were considered significant at $p<0.05$. 
Author Contributions: Conceptualization, H.D. and C.T.; Investigation, E.M.B., R.M.; Data curation, R.M. and C.T.; Writing-original draft preparation, Review and editing, E.M.B., R.M., H.D. and C.T.; Supervision, H.D. and C.T.; Project administration, H.D. and C.T.; Funding acquisition, H.D.

Funding: This research was funded by the Spanish Ministry of Science and Innovation, grants number CTM2009-12664 and CTM2012-38095, partially funded by FEDER-European funds.

Acknowledgments: Authors are grateful to the Department of Analytical Chemistry, Nutrition and Bromatology (University of Santiago de Compostela, Spain) for the technical support. Balboa, E.M. is grateful to the Spanish Ministerio de Economía y Competitividad (grant reference CTM2009-12664).

Conflicts of Interest: The authors declare no conflict of interest. The funders had no role in the design of the study; in the collection, analyses, or interpretation of data; in the writing of the manuscript, or in the decision to publish the results.

\section{References}

1. Zhang, Z.; Zhang, Q.; Wang, J.; Zhang, H.; Niu, X.; Li, P. Preparation of the different derivatives of the low-molecular-weight porphyran from Porphyra haitanensis and their antioxidant activities in vitro. Int. J. Macromol. 2009, 45, 22-26. [CrossRef] [PubMed]

2. Karnjanapratum, S.; You, S. Molecular characteristics of sulfated polysaccharides from Monostroma nitidum and their in vitro anticancer and immunomodulatory activities. Int. J. Biol. Macromol. 2010, 48, 311-318. [CrossRef] [PubMed]

3. Wijesekara, I.; Pangestuti, R.; Kim, S.K. Biological activities and potential health benefits of sulfated polysaccharides derived from marine algae. Carbohyd. Polym. 2011, 84, 14-21. [CrossRef]

4. Kang, H.K.; Deo, C.H.; Park, Y. The effects of marine carbohydrates and glycosylated compounds on human health. Int. J. Mol. Sci. 2015, 16, 6018-6056. [CrossRef] [PubMed]

5. Holdt, S.L.; Kraan, S. Bioactive compounds in seaweed: Functional food applications and legislation. J. Appl. Phycol. 2011, 23, 543-597. [CrossRef]

6. Zhao, Z.; Yang, X.; Gong, Z.; Pan, M.; Han, Y.; Liu, Y. Antioxidant activities of crude phlorotannins from Sargassum hemiphyllum. J. Huazhong Univ. Sci. Technol. Med. Sci. 2016, 36, 449-45526. [CrossRef] [PubMed]

7. Plaza, M.; Cifuentes, A.; Ibáñez, E. In the search of new functional food ingredients from algae. Trends Food Sci. Technol. 2008, 19, 31-39. [CrossRef]

8. Sureh, V.; Anbazhagan, C.; Senthilkumar, D.; Senthilkumar, N.; Kannan, S.; Rengasamy, R.; Palani, P. Stabilization of mitochondrial and microsomal function of fucoidan from Sargassum plagiophyllum in diethylnitrosamine induced hepatocarcinogenesis. Carbohyd. Polym. 2013, 92, 1377-1385. [CrossRef]

9. Mori, J.; Matsunaga, T.; Takahashi, S.; Hasegawa, C.; Saito, H. Inhibitory activity on lipid peroxidation of extracts from marine brown algae. Phytother. Res. 2003, 17, 549-551. [CrossRef]

10. Murugan, K.; Iyer, V.V. Differential growth inhibition of cancer cell lines and antioxidant activity of extracts of red, brown, and green marine alge. In Vitro Cell. Dev. Biol. Anim. 2013, 49, 324-334. [CrossRef]

11. Shao, P.; Chen, X.; Sun, P. In vitro antioxidant and antitumor activities of different sulfated polysaccharides isolated from three algae. Int. J. Biol. Macromol. 2013, 62, 155-161. [CrossRef] [PubMed]

12. Motshakeri, M.; Ebrahimi, M.; Goh, Y.M.; Matanjun, P.; Mohamed, S. Sargassum polycystum reduces hyperglycaemia, dyslipidaemia and oxidative stress via increasing insulin sensitivity in a rat model of type 2 diabetes. J. Sci. Food Agric. 2013, 93, 1772-1778. [CrossRef] [PubMed]

13. Motshakeri, M.; Ebrahimi, M.; Goh, Y.M.; Othman, H.H.; Bejo, M.H.; Mohamed, S. Effects of brown seaweed (Sargassum polycystum) extracts on kidney, liver, and pancreas of type 2 diabetic rat model. Evid. Based Complement. Altern. Med. 2014, 379407. [CrossRef] [PubMed]

14. Flórez-Fernández, N.; López-García, M.; González-Muñoz, M.J.; Vilariño, J.M.; Domínguez, H. Ultrasound-assisted extraction of fucoidan from Sargassum muticum. J. Appl. Phycol. 2017, 29, 1553-1561. [CrossRef]

15. González-López, N.; Moure, A.; Domínguez, H. Hydrothermal fractionation of Sargassum muticum biomass. J. Appl. Phycol. 2012, 24,1569-1578. [CrossRef]

16. Balboa, E.M.; Rivas, S.; Moure, A.; Domínguez, H.; Parajó, J.C. Simultaneous extraction and depolymerization of fucoidan from Sargassum muticum in aqueous media. Mar. Drugs 2013, 11, 4612-4627. [CrossRef] [PubMed]

17. Balboa, E.M.; Moure, A.; Domínguez, H. Valorization of Sargassum muticum biomass according to the biorefinery concept. Mar. Drugs 2015, 1, 3745-3760. [CrossRef] [PubMed] 
18. Álvarez-Viñas, M.; Flórez-Fernández, N.; González-Muñoz, M.J.; Domínguez, H. Influence of molecular weight on the properties of Sargassum muticum fucoidan. Algal Res. 2019, 38, 101393. [CrossRef]

19. Valko, M.; Izakovic, M.; Mazur, M.; Rhodes, C.J.; Telser, J. Role of oxygen radicals in DNA damage and cancer incidence. Mol. Cell. Biochem. 2004, 266, 37-56. [CrossRef]

20. Storz, P. Reactive oxygen species in tumor progression. Front. Biosci. 2005, 10, 1881-1896. [CrossRef]

21. Halliwell, B. Reactive species and antioxidants. Redox Biology is a fundamental theme of aerobic life. Plant Physiol. 2006, 141, 312-322. [CrossRef] [PubMed]

22. Porrini, M.; Riso, P.; Brusamolino, A.; Berti, C.; Guarnieri, S.; Visioli, F. Daily intake of a formulated tomato drink affects carotenoid plasma and lymphocyte concentrations and improves cellular antioxidant protection. Br. J. Nutr. 2005, 93, 93-99. [CrossRef] [PubMed]

23. Gawrieh, S.; Opara, E.C.; Koch, T.R. Oxidative stress in nonalcoholic fatty liver disease: Pathogenesis and antioxidant therapies. J. Investig. Med. 2004, 52, 506-514. [PubMed]

24. Zaragozá, M.C.; López, D.; Sainz, M.P.; Poquet, M.; Perez, J.; Puig-Parrellada, P.; Mármol, F.; Simonetti, P.; Gardana, C.; Lerat, Y.; et al. Toxicity and Antioxidant activity in vitro and in vivo of two Fucus vesiculosus extracts. J. Agric. Food Chem. 2008, 56, 7773-7780. [CrossRef] [PubMed]

25. Tas, S.; Celikler, S.; Ziyanok-Ayvalik, S.; Sarandol, E.; Dirican, M. Ulva rigida improves carbohydrate metabolism, hyperlipidemia and oxidative stress in streptozotocin-induced diabetic rats. Cell Biochem. Funct. 2011, 29, 108-113. [CrossRef] [PubMed]

26. Dahech, I.; Belghith, K.S.; Hamden, K.; Feki, A.; Belghith, H.; Mejdoub, H. Oral administration of levan polysaccharides reduces the alloxan-induced oxidative stress in rats. Int. J. Biol. Macromol. 2011, 49, 942-947. [CrossRef]

27. Kim, M.S.; Kim, J.Y.; Choi, W.H.; Lee, S.S. Effects of seaweed supplementation on blood glucose concentration, lipid profile and antioxidant enzyme activities in patients with type 2 diabetes mellitus. Nutr. Res. Pract. 2008, 2, 62-67. [CrossRef]

28. Schroder, H. Protective mechanisms of the Mediterranean diet in obesity and type 2 diabetes. J. Nutr. Biochem. 2007, 18, 149-160. [CrossRef]

29. Basu, S. Carbon tetrachloride-induced lipid peroxidation: Eicosanoid formation and their regulation by antioxidant nutrients. Toxicology 2003, 189, 113-127. [CrossRef]

30. Kang, K.A.; Bu, H.D.; ParK, D.S.; Go, G.M.; Jee, Y.; Shin, T.; Hyun, J.W. Antioxidant activity of ethanol extract of Callophyllis japonica. Phytother. Res. 2005, 19, 506-510. [CrossRef]

31. Guerra Dore, C.M.P.; Faustino Alves, M.G.; Luiza Sheyla, E.; Pofírio Will, L.S.; Costa, T.G.; Sabry, D.A.; de Souza Rêgo, L.A.R.; Accordo, C.M.; Rocha, H.A.O.; Guimarães, A.; et al. Sulfated polysaccharide, fucans, isolated from brown algae Sargassum vulgare with anticoagulant, antithrombotic, antioxidant and anti-inflammatory effects. Carbohyd. Polym. 2013, 91, 467-475. [CrossRef] [PubMed]

32. Kellogt, J.; Lila, M.A. Chemical in vitro assessment of Alaskan Coastal vegetation antioxidant capacity. J. Agric. Food Chem. 2013, 61, 11025-11032. [CrossRef] [PubMed]

33. Marudhupandi, T.; Kumar, T.T.; Senthil, S.L.; Devi, K.N. In vitro antioxidant properties of fucoidan fractions from Sargassum tenerrimum. Pak. J. Biol. Sci. 2014, 17, 402-407. [CrossRef] [PubMed]

34. Rocha de Souza, M.C.; Marques, C.T.; Guerra Dore, C.M.; Ferreira da Silva, F.R.; Oliveira Rocha, H.A.; Lisboa Leite, E. Antioxidant activities of sulfated polysaccharides from brown and red seaweeds. J. Appl. Phycol. 2007, 19, 153-160. [CrossRef] [PubMed]

35. Sabeena, F.K.N.; Jacobsen, C. Phenolic compounds and antioxidant activities of selected species of seaweeds from Danish coast. Food Chem. 2013, 138, 1670-1681. [CrossRef] [PubMed]

36. Muroney, N.C.; O'Grady, M.N.; O’Doherty, J.V.; Kerry, J.P. Addition of seaweed (Laminaria digitata) extracts containing laminarin and fucoidan to porcine diets: Influence on the quality and shelf-life of fresh pork. Meat Sci. 2012, 92, 423-429. [CrossRef] [PubMed]

37. Gorham, J.; Lewey, S.A. Seasonal changes in the chemical composition of Sargassum muticum. Mar. Biol. 1984, 80, 103-107. [CrossRef]

38. Lowry, O.H.; Rosebrough, N.J.; Far, A.L.; Randall, R.J. Protein measurement with the Folin phenol reagent. J. Biol. Chem. 1951, 193, 267-275.

39. Fairbanks, V.F.; Klee, G.G. Biochemical aspects of hematology. In Fundamentals of Clinical Chemistry, 3rd ed.; Tiez, N.W., Ed.; W.R. Saunders Co.: Philadelphia, PA, USA, 1987; pp. 197-212. 
40. Esterbauer, H.; Cheeseman, K.H. Determination of aldehydic lipid peroxidation products: Malonaldehyde and 4-hydroxynonenal. Methods Enzymol. 1990, 186, 407-421.

41. Beauchamp, C.; Fridovich, I. Superoxide dismutase: Improved assays and an assay applicable to acrylamide gels. Anal. Biochem. 1971, 44, 276-287. [CrossRef]

42. Paglia, D.E.; Valentine, W.N. Studies on the quantitative and qualitative characterization of erythrocyte glutathione peroxidase. J. Labor. Clin. Med. 1967, 70, 158-169.

43. Aebi, H. Catalase in vitro. Methods Enzymol. 1984, 105, 121-126. [PubMed]

(C) 2019 by the authors. Licensee MDPI, Basel, Switzerland. This article is an open access article distributed under the terms and conditions of the Creative Commons Attribution (CC BY) license (http://creativecommons.org/licenses/by/4.0/). 